To cite: DM Chirwa 'Children's rights, domestic alternative care frameworks and judicial responses to restrictions on inter-country adoption: A case study of Malawi and Uganda' (2016) 16 African Human Rights Law Journal 117-144

\title{
Children's rights, domestic alternative care frameworks and judicial responses to restrictions on inter-country adoption: A case study of Malawi and Uganda
}

\author{
Danwood M Chirwa \\ Professor of Law, University of Cape Town, South Africa
}

\begin{abstract}
Summary
As the problem of a lack of parental care over the years has worsened in Africa, states have not adopted sufficient alternative care measures to address the needs of the children involved. To date, many countries in Africa remain suspicious of inter-country adoption and, hence, consider it as a subsidiary means of providing alternative care to children deprived of a family environment. Through a study of the legal frameworks and court decisions of Malawi and Uganda, the article demonstrates that some of the most common restrictions on inter-country adoption do not serve the best interests and rights of the child. As a result, the courts in these countries have gone out of their way to bypass or ignore these restrictions, and have sanctioned inter-country adoptions. In doing so, the courts have put themselves at risk of being accused of law making. Due to the absence of an appropriate legal framework, these courts have also struggled to make inter-country adoption orders that are capable of being effectively
\end{abstract}

LLB Hons (Malawi) LLM (Pretoria) PhD (Western Cape); danwood.chirwa@uct.ac.za. Research for this article was made possible by the National Research Foundation and the Centre of African Studies, University of Cambridge, where I spent time as a visiting research fellow from 1 October 2014 to 31 March 2015. I would like to thank Prof Harri Englund, the staff at the Centre and other visiting research fellows from Africa for their kindness and support. I received invaluable assistance from Prof Christopher Mbazira and Dr Livingstone Sewanyana on my research visit to Uganda in mid-2014, for which I am also most grateful. 
monitored and supervised by the state authorities in the sending and receiving states. The protection of the rights of children in need of parental care requires that states treat inter-country adoption as a worthy alternative care option that should not be subjected to undue restrictions, but regulated sufficiently to protect and promote the best interests and rights of the child.

Key words: alternative care; inter-country adoption; children's rights; Malawi; Uganda; Africa

\section{Introduction}

A lack of parental care remains one of the most glaring failings of the twenty-first century. Although this problem is present throughout the world, it is arguably most acute in Africa. ${ }^{1}$ Even as the international community recognised children as rights holders by adopting the Convention on the Rights of the Child $(C R C)^{2}$ in 1989 , children remain the most affected by poverty and a lack of access to basic services.

In most African traditional societies, the problem of a lack of parental care was not as acute as it is now, partly because of the communitarian nature of these societies, which meant that a child belonged to the clan, the village or the whole community of which it was centrally a part. With time, community ties have increasingly weakened and broken down, leaving children whose parents have died without social protection from the extended family. ${ }^{3}$

1 See, eg, UNICEF 'Africa's orphaned generations' (2003), http://www.unicef.org/ sowc06/pdfs/africas_orphans.pdf (accessed 18 June 2015), where UNICEF found that 11 million children under the age of 15 were orphans due to HIV/AIDS and predicted that this number would almost double by 2010. This represents a mere fraction of all orphaned children in the region. The same report noted that there were more than 35 million orphans in sub-Saharan Africa by 2003, representing $12 \%$ of all children in the region. These estimates have proved to be correct. In particular, a recent UNICEF report reveals that ' 67 per cent of all the children in the thirty countries suffer from two to five deprivations crucial to their survival and development, corresponding to 247 million out of a total of 368 million children below the age of 18 living in these thirty countries'. M de Milliano \& I Plavgo 'Analysis of child poverty and deprivation in sub-Saharan Africa' Office Research Working Paper WP 2014-19, http://www.unicef-irc.org/publications/pdf/ ccmoda_africa.pdf (accessed 20 June 2015). See also M Turshen 'Child poverty in Africa' (2008) 35 Review of African Political Economy 494-500; T Abebe 'Orphanhood, poverty and the care dilemma: Review of global policy trend' (2009) 7 Social Work and Society International Online Journal.

2 GA Res 44/25, annex, 44 UN GAOR Supp (No 49) 167, UN Doc A/44/49 (1989), entered into force 2 September 1990.

3 J Iwelunmor et al 'Family systems and HIV/AIDS in South Africa' (2006) 27 International Quarterly of Community Health Education 321 322; RS Katapa 'Caretakers of AIDS patients in rural Tanzania' (2004) 15 International Journal of STD and AIDS 673-678; J Seeley et al 'The extended family and support for people with AIDS in a rural population in South West Uganda: A safety net with holes?' (1993) 5 AIDS Care 117-122. 
As more and more children become orphans or lack parental care, states have not established sufficient alternative care options to accommodate the needs of these children. ${ }^{4}$ Yet, many countries in Africa remain suspicious of inter-country adoption, instead preferring domestic solutions. As a result, restrictions are imposed on the use of inter-country adoption as an alternative care option for children deprived of parental care.

The reluctance to embrace inter-country adoption arises from several concerns about this practice. ${ }^{5}$ They also feed on an ambiguity in international law that suggests that inter-country adoption is a measure of last resort. The principle of last resort has been interpreted by some to mean that inter-country adoption cannot be used before in-country options have been exhausted. ${ }^{6}$ This interpretation stands in stark opposition to the view advocated in this article, which considers inter-country adoption as one of the alternative care options to be considered on a case-by-case basis alongside other care options, and to be used when it stands a better chance of serving the best interests of a particular child than other options.

The article examines the legal restrictions placed on inter-country adoption in two African countries, Malawi and Uganda, and how the courts have responded to these restrictions when applying the law in specific cases. Both these countries have experienced a significant rise in the number of children who lack parental care. ${ }^{7}$ Yet, both countries place legal restrictions on the use of inter-country adoption. These restrictions operate in two distinct legislative frameworks of alternative child care. Malawi's legislation establishes no clear hierarchical

4 See generally UNICEF 'Alternative care for children in Southern Africa: Progress, challenges and future directions' (2008), http://www.unicef.org/esaro/ Alternative_care_responses_ESAR_06_2008.pdf (accessed 4 April 2016); L Richter et al (eds) Family and community interventions for children affected by AIDS (2004).

5 These include arguments that inter-country adoption represents a form of imperialism since most African children are adopted by parents from the West; that it completely severs the child from his or her cultural or religious setting; that it undermines the rights of poor parents who are seen as incompetent parents and not deserving of being parents; and that it is used as a mechanism for diverting children into trafficking networks, prostitution and exploitative work. These have been amply discussed and critiqued elsewhere. See eg S Dillon 'Making legal regimes for intercountry adoption reflect human rights principles: Transforming the United Nations Convention on the Rights of the Child with the Hague Convention on Intercountry Adoption' (2003) 21 Boston University International Law Journal 179; B Mezmur 'Inter-country adoption as a measure of last resort in Africa: Advancing the rights of a child rather than a right to a child' (2009) International Journal on Human Rights 82.

6 See eg B Mezmur 'From Angelina (to Madonna) to Zoe's Ark: What are the A-Z lessons for inter-country adoptions in Africa?' (2009) International Journal of Law, Policy and the Family 145.

7 By 2012, at least 8,5 million of Malawi's total population were children. Approximately $13 \%$ of this child population had lost one or both parents, and was at risk of lacking parental care. Overall, about 1,2 million children experienced 'reduced parental care'. About 12000 of these lived in child-headed households, while about 6000 lived in institutional care. UNICEF 'Malawi child protection strategy: 2012-2016', http://www.unicef.org/malawi/MLW_resources_child protec strategy.pdf (accessed 20 November 2014). By 2012, about 12000 children were 
structure for alternative care options, while Ugandan legislation does. Curiously, in both countries the courts have found it difficult to apply the restrictions on inter-country adoption in specific cases without undermining the best interests of the child. Through these two cases studies, the article seeks to argue that inter-country adoption should be considered as possible alternative care without having to subordinate it to other care options. In other words, inter-country adoption should be prescribed as a possibility along other alternative care options in every case where a child is in need of alternative family care. What should ultimately turn the scales in favour of any of the available alternative care options is the principle of the best interests and the totality of the child's rights. This is a decision that ought to be made on a case-by-case basis, taking full account of the child's specific circumstances.

\section{Inter-country adoption: Subsidiary or primary option?}

Article 21(b) of the CRC and article 24(b) of the African Charter on the Rights and Welfare of the Child (African Children's Charter) ${ }^{8}$ provide the basis for the view that inter-country adoption should be given less priority in alternative care solutions.

Article 21(b) of the CRC provides:

States Parties that recognize and/or permit the system of adoption shall ensure that the best interests of the child shall be the paramount consideration and they shall:

..

Recognize that inter-country adoption may be considered as an alternative means of child's care, if the child cannot be placed in a foster or an adoptive family or cannot in any suitable manner be cared for in the child's origin ...

Article 24(b) of the African Children's Charter provides:

States Parties which recognise the system of adoption shall ensure that the best interests of the child shall be the paramount consideration and they shall:

confirmed to be living in institutional care (orphanages and other approved homes estimated to be in the region of 600) and an additional 45000 were in institutional care, while approximately 10000 more lived on the streets. M Riley 'Baseline study: The state of institutional care in Uganda', Ministry of Gender, Labour and Social Development, Uganda (2012); ChildFund 'ChildFund receives USAID grant to assist orphaned and homeless children in Uganda' (2014), https:// www.childfund.org/uploadedFiles/public_site/media/press_releases/USAID\%20Gr ant\%20Final\%2081314.pdf (accessed 20 June 2015).

8 Charter OAU Doc CAB/LEG/24.9/49 (1990), entered into force 29 November 1999. 
recognise that inter-country adoption in those states who have ratified or adhered to the International Convention on the Rights of the Child or this Charter, may, as a last resort, be considered as an alternative of child's care, if the child cannot be placed in a foster or an adoptive family or cannot in any suitable manner be cared for in the child's country of origin ...

On the face of it, it could be said for countries that recognise adoption that both the CRC and the African Children's Charter consider intercountry adoption as a subsidiary option. ${ }^{9}$ For example, the African Children's Charter specifically states that inter-country adoption may be considered as a last resort, while the CRC states that inter-country adoption may be considered as an option that may be taken if the child cannot be provided with other means of alternative care. Furthermore, the CRC states that placement in a suitable institution could be made 'if it is necessary'. ${ }^{10}$ The same caution is not attached to foster placement, in-country adoption or Kafalah.

However, this view cannot be sustained. For one thing, both these articles show that adoption is not mandatory. The obligation to ensure that adoption fulfils the best interests of the child applies only to countries that recognise adoption. For another, both the CRC and the African Children's Charter leave it to states to determine the appropriate forms of alternative care for children. Therefore, even when they appear to suggest what forms of alternative care might be adopted and preferred, the two treaties do so using directory rather than obligatory terms. For example, the African Children's Charter states that inter-country adoption 'may, as a last resort, be considered as an alternative of child's care'. ${ }^{11}$ Since neither treaty prescribes an exhaustive list of alternative care options nor defines precisely what each care option entails, states have a discretion to devise more alternative care options and to reconfigure the well-known ones so that they better serve the best interests of children. For example, institutional care is widely considered unfavourable, mainly because it does not allow the child to grow up in a family environment or make it possible for the child to participate in the normal social life of his or

9 Mezmur, eg, appears to endorse such a hierarchy, although he argues that it should not be applied rigidly. He also cites UNICEF, which also recommends a hierarchy of alternative care options and prioritises family-based options over institutionalisation, permanent solutions over temporary solutions, and national solutions over those involving more than one country. See Mezmur (n 5 above) 85-98, citing UNICEF 'Intercounty adoption' (1998) Innocent Digest 5. It now appears that UNICEF has moved from that view as its new report shows. See $\mathrm{N}$ Cantwell 'The best interests of the child in intercounty adoption', UNICEF Office of Research 2014 49-70, http://www.unicef-irc.org/publications/pdf/unicef\%20 best\%20interest\%20document_web_re-supply.pdf (accessed 4 April 2016).

10 Art 20(3).

11 See art 24(b) (my emphasis). Art 21(b) of the CRC also uses 'may'. 
her community. ${ }^{12}$ It is possible, however, for institutional placement to be arranged in such a way that the child is allowed to maintain a meaningful relationship with his or her relatives.

In addition to the forms of alternative care suggested by the CRC and the African Children's Charter, child-headed households and group homes are new child care options that have been developed. ${ }^{13}$ States can devise variations of foster care, adoption, institutional care, or care options that combine any of these. Whatever care options are adopted, their suitability has to be measured with reference to the child's best interests, the entirety of the child's rights and the specific circumstances of the child.

The conclusion of this discussion is that a rigid legal framework that prescribes beforehand what forms of alternative care should be prioritised may not in specific cases ensure the protection and advancement of the child's best interests and rights. Neither the CRC nor the African Children's Charter can be interpreted plausibly as suggesting such a rigid framework. States have a singular duty to provide alternative care for children deprived of a family environment or whose best interests require that they be separated from their parents or guardians. This duty implies an obligation to devise as many suitable options as possible to cater for the different personal circumstances of children. The suitability of each form of alternative care and its likely impact on the child need to be considered on a case-by-case basis, bearing in mind the best interests of the child.

\section{Legislative framework}

\subsection{Malawi}

Until very recently, legal issues concerning children in Malawi were dealt with in fragments and haphazardly by various Acts of parliament. Of these, the Children and Young Persons Act ${ }^{14}$ and the Adoption of Children Act ${ }^{15}$ were solely concerned with children despite the fact that they did not do so comprehensively.

12 See generally UNICEF Children in institution: The beginning of the end? The cases of Italy, Spain, Argentina, Chile and Uruguay (2003), http://www.unicef- irc.org/ publications/pdf/insight8e.pdf (accessed 4 April 2016); K Browne 'The risk of harm to young children in institutional care' (2009), Save the Children, http:// www.kinnected.org.au/assets/resources/23.The_Risk_of_Harm.pdf (accessed 4 April 2016).

13 See generally NA Phaladze 'The plight of family caregivers in homes-based care in Botswana' (2003) 33 Botswana Notes and Records 73; C Phillips 'Child-headed households: A feasible way forward, or an infringement of children's rights to alternative care?' (2011), http://www.charlottephillips.org/eBook\%20Childheaded\%20Households.pdf (accessed 4 April 2016); LM Richter \& C Desmond 'Targeting AIDS orphans and child-headed households: A perspective from national surveys in South Africa, 1995-2005' (2008) 20 AIDS Care 1019.

14 Ch 26:03 Laws of Malawi, now repealed.

15 Ch 26:01 Laws of Malawi. 
These Acts have a long history, both having been enacted in the colonial era. The former, modelled on the English Act of 1933, was first enacted in 1946 as the Children and Young Persons Ordinance, as part of a package of laws aimed at improving the treatment of African offenders in colonial territories. Despite its seemingly general title, its preoccupation was with children in conflict with the law rather than with children in need of alternative care. The renaming of this legislation as an Act in $1969^{16}$ brought about some changes to the Ordinance but, on the whole, it retained its criminal justice focus and approach.

Therefore, it is not surprising that the Children and Young Persons Act saw child destitution and a lack of parental care more as an issue of child delinquency than an issue of the denial of the human rights of the affected children. Section 20(1) of the Act defined a child in need of care, control and supervision as one

who, having no parent or guardian or a parent or guardian unfit or unable to exercise proper care and guardianship, or not exercising proper care and guardianship, is either falling into bad associations, or exposed to moral or physical danger, or beyond control.

It was taken as evidence that the child was exposed to danger if he or she was found destitute, wandering from place to place without a permanent place of abode or the means of subsistence, begging or loitering. ${ }^{17}$ Apart from the narrowness of the definition of children in need of protection and care, ${ }^{18}$ the Act prescribed limited options for the care of such a child. These included an order to send the child to an approved school; to commit the child to the care of a fit person (whether a relative or not) who was willing to take care of the child; or to order the parent or guardian to enter into a recognisance to exercise proper care and guardianship. ${ }^{19}$

Like the Children and Young Persons Act, the Adoption of Children Act was enacted at the height of colonialism, in $1949,{ }^{20}$ in order to facilitate the adoption of African children by foreign residents in the then Nyasaland. ${ }^{21}$ The assumption was that Africans would continue to use their informal systems of providing child care based on the applicable African customary laws, customs and traditions. Thus, the type of adoption recognised by this Act is that known to English law,

16 Act 7 of 1969 . The Act was amended several times thereafter by Acts 51 of 1971 , 24 of 1972, 5 of 1976, 22 of 1989 and 6 of 1990.

17 Sec 20(2) Children and Young Persons Act.

$18 \mathrm{Eg}$, it did not mention children who have been victims of domestic violence, trafficking, sexual abuse or exploitation, or child refugees and internally-displaced children. It also suggests that children who lack parental care per se without falling into bad associations or being exposed to moral or physical danger did not need alternative care.

19 Sec 22(1) Children and Young Persons Act.

20 As Act 13 of 1949. It was subsequently amended by Acts 19 of 1957, 22 of 1958, 8 of 1963 , and 21 of 1967.

21 UNICEF 'Malawi fact sheet: Justice for children', http://www.unicef.org/malawi/ MLW_factsheet_justice.pdf (accessed 20 November 2014). 
resulting in the termination of the pre-existing parent-child relationship. ${ }^{22}$ Although such dualist approach to adoption was not restricted to this field of law, ${ }^{23}$ the separation of adoption from the province of the alternative care covered, albeit in rudiments, by the Children and Young Persons Act, created and has continued to present an obstacle to the integration of adoption into alternative care in Malawi.

It is clear from the provisions of the Adoption Act that it does not see adoption primarily as a means of providing alternative care. Rather, adoption is conceived largely from the perspective of the rights and privileges of adults. To begin with, the Act pays little attention to the question of the adoptability of children. All it says is that any child under the age of 21 years, who has never been married and is resident in Malawi, may be adopted. ${ }^{24}$ It does not specify any concrete adoptability criteria related to the child's lack of parental care or the need to protect the child from destitution, abuse, exploitation or domestic violence. In contrast to the scant attention given the child's adoptability, the Act dedicates considerable attention to the issue of the eligibility of adoptive parents.

An analysis of the eligibility requirements will prove that some of them are rational and others irrational. The Act states that an adoption can be made in favour of single adults or jointly in favour of two spouses. ${ }^{25}$ Where the application is made by one applicant, the consent of his or her spouse has to be obtained unless the court dispenses with the need for this. ${ }^{26}$ There is nothing concerning about these provisions. The rest is hardly rational and appears to be outdated. For example, the Act states that the applicant must be at least 25 years old and there must be an age difference of at least 21 years between the applicant and the child unless the applicant is related to the child (within the prohibited degrees of consanguinity). ${ }^{27}$ The requirement as to the difference in age between the child and the adoptive parent was presumably intended to prevent sexual abuse but, with respect, it cannot serve as a guarantee against such abuse. There is no basis for saying that a parent who is older than a child by more than 21 years is less likely to abuse a child than a parent who is less than 21 years older than the child.

22 See sec 6 of the Adoption of Children Act.

23 Dualist laws based largely on race were common then, especially as far as personal laws were concerned, such as in fields of marriage, inheritance, divorce and child maintenance. Africans (black Malawians) were generally left to be governed in these areas by the African customary laws applicable to them, unless they opted out of these laws by expressly acting under the Acts of parliament designed for non-Africans.

24 See secs 2 and 3(5) of the Adoption of Children Act.

25 See sec 2(3) of the Adoption of Children Act.

26 See sec 3(4) of the Adoption of Children Act.

$27 \mathrm{Sec} 3(1)$ Adoption of Children Act. 
A more bizarre requirement relates to the gender of the adoptive parents vis-à-vis that of the child. According to section 3(2) of the Act, a sole male applicant cannot adopt a female child unless the court is satisfied that special circumstances justify such an adoption. The same is the case with single female applicants vis-à-vis male children. ${ }^{28}$ This Act was based on outmoded conceptions of sexual orientation, and if the intention was to prevent adoptive parents from sexually abusing their adopted children, this requirement cannot serve that purpose as it allows adoptive parents of same-sex or bisexual orientation to adopt children of their own sex. ${ }^{29}$

The last requirement for an adoptive parent is that he or she must be resident in Malawi. ${ }^{30}$ It is this requirement that has been the subject of much controversy and forms the focus of much of the discussion in the article.

To its credit, the Act regards decisions on adoption as serious, requiring the involvement of the courts. Thus, an adoption can only be made by a court of the appropriate jurisdiction in a prescribed form. ${ }^{31}$ The court is enjoined to ensure that the consent of the parents or any other person whose consent is required by the Act has been given, that such consent is informed or has been given after being fully appraised of the effects of the adoption, that no person has received any payment in consideration of the adoption and, more importantly, that the adoption is necessary for the welfare of the child, due regard being given, subject to the age and understanding of the child, to the wishes of the child. ${ }^{32}$ As an additional measure of protection of the child, a court may make an interim order of adoption under certain conditions pending the granting of the final adoption order. ${ }^{33}$

As is clear from the above, the Adoption of Children Act and the Children and Young Persons Act, considered together, provided a patchy framework for dealing with children in need of parental care or requiring state protection from abuse or violence. It is a framework that fell short of the expectations of the new Constitution adopted in 1994, which recognises children as rights holders who have the right to know and be raised by their parents, the right to family protection, the right to development, the right to education and the right to equality before the law and equal protection, to mention just a few

$28 \mathrm{Sec} 3(2)$ Adoption of Children Act.

29 In both countries, homosexuality is prohibited by their respective criminal codes, although their constitutions can be interpreted to mean that such criminalisation is unconstitutional. However, since one does not have to disclose one's sexual orientation, there is nothing that prevents prospective adoptive parents of samesex orientation to adopt.

30 Sec 3(5) Adoption of Children Act.

31 This may be the High Court or, at the option of the applicant, a Resident Magistrate's Court, or First Grade Magistrate's Court. See sec 9 of the Adoption Act.

32 Sec 4 of the Act.

33 See sec 7 of the Adoption of Children Act. 
rights. ${ }^{34}$ Importantly, Malawi acceded to the CRC on 2 January 1991 and to the African Children's Charter on 16 September 1999. The former, having been acceded to before the new Constitution came into force, ${ }^{35}$ is binding and justiciable before Malawian courts. ${ }^{36}$

The shortcomings of these laws, considered against these treaties and the Constitution, relate to the conflation of the lack of parental care and child destitution with child or juvenile delinquency; the limited options for the provision of alternative care; the failure to locate adoption and inter-country adoption within the broader context of alternative care; and the failure to provide a comprehensive framework for the regulation of inter-country adoption.

The repeal of the Children and Young Persons Act by the Child Care, Protection and Justice Act, ${ }^{37}$ enacted in 2010, ameliorated some of these concerns. For example, the new Act is more comprehensive and covers three broad children's rights themes: child care broadly conceived as family and alternative care; the protection of children from harm; and the protection of children accused of having offended against the criminal law. Its provisions on family care are in some ways radical, especially insofar as they seek to abolish the parallel system of laws governing the rights and responsibilities in a marriage, to prescribe equal parental responsibilities towards children, and to protect equal rights to child custody and to inheritance. ${ }^{38}$

The specific provisions regarding children in need of care also represent a marked improvement on the Children and Young Persons Act. Not only do they address the situation of children who have no surviving parents, guardians or traceable relatives and children who have been abandoned and neglected by their parents, but they also deal with the circumstances of children involved in begging, loitering and other illegal activities and children who are under threat or are actual victims of exploitation, violence, trafficking and abuses of all kinds. ${ }^{39}$ The Act also makes provision for the appointment of guardians, ${ }^{40}$ for the establishment of public foster homes ${ }^{41}$ and the

34 See sec 23 of the Constitution.

35 The Constitution came into force on 18 June 1994.

36 See sec 211(2) of the Constitution, as interpreted in S Kalinda $v$ Limbe Leaf Tobacco Ltd Civil Cause 542 of 1995 (unreported); Malawi Telecommunications Ltd $v$ Makande \& Omar MSCA Civil Appeal 2 of 2004 (unreported).

37 Act 22 of 2010.

$38 \mathrm{Eg}$, the Act codifies the joint primary responsibility of parents for raising their children, and clarifies the laws and procedures governing the determination of parentage. See secs 3 and 5-7. These provisions mark a fundamental break with African customary law which defines parental responsibilities through a gender lens and based on whether the marriage is governed by matrilineal or patrilineal systems of law.

39 See sec 23.

40 See secs 38-45.

41 See $\sec 46$. 
accreditation of private foster homes, ${ }^{42}$ for the responsibilities of local authorities towards children in need of care and protection, ${ }^{43}$ for the protection of children from undesirable practices, ${ }^{44}$ and for the establishment of reformatory centres and safety homes. ${ }^{45}$

However, the Act fails to integrate adoption in its framework. Just as was the case previously, the issue of adoption has been left to a separate legislative review process aimed at amending the Adoption of Children Act. This reform initiative has not yet come to fruition, which means that the Adoption of Children Act remains operational. It is thus unclear, for example, whether the new provisions governing guardianship contained in the Child Care, Protection and Justice Act are meant to supersede those concerning adoption under the Adoption of Children Act. ${ }^{46}$ This, particularly, is a problem given that some of the circumstances that may justify a guardianship order mirror those under which an adoption may be granted. ${ }^{47}$

\subsection{Uganda}

Ugandan child laws before the Children Act ${ }^{48}$ was enacted in 1997 were as fragmented as Malawian laws before Malawi's Child Care, Protection and Justice Act was passed in 2010. Although an attempt was made in Uganda to separate issues of child care and protection from child reformation by enacting two separate statutes dedicate to these themes, the Approved Schools Act ${ }^{49}$ and the Reformatory Schools Act, ${ }^{50}$ both of which were inherited from the colonial era, child care was largely conceived in narrow terms that targeted the socalled 'problematic child'. The Approved Schools Act defined a child in need of care as one who was beyond parental guidance or was involved in immoral behaviour, loitering or street begging. Indeed, such children were considered to be as problematic as those accused of having committed or been convicted of criminal offences; the difference, if any, lay in degree only. Thus, children in need of such care were committed to approved schools where child or juvenile offenders were also kept. ${ }^{5}$ The procedure for determining which

\footnotetext{
42 See $\sec 47$.

43 See secs 70-77.

44 See secs 78-85.

45 See secs 157-176.

46 Although this Act is currently under review, it remains in force.

47 See sec 41 which provides that a guardian may be appointed upon an application by any person where the child's parents are no longer living, cannot be found or are not living together and it is in the best interests of the child that a guardian be appointed. There are no restrictions based on the nationality of the applicant. As will be seen below, guardianship has been used in Uganda to bypass restrictions on inter-country adoptions.

48 Ch 59 Laws of Uganda.

491964 Revision, ch 110 Laws of Uganda, repealed.

501964 Revision, ch 111 Laws of Uganda, repealed.

51 See Department of Probation and Social Welfare Report of the Child Law Review Committee (1992) 28.
} 
child was in need of care was coercive and lacked guarantees of procedural fairness. ${ }^{52}$

The provisions regarding foster placement in the Approved Schools Act were also inadequate. For example, there was no provision for the supervision of fosterage. ${ }^{53}$ For its part, the Reformatory Schools Act provided for the treatment of children who offended against the criminal law, a more extreme category of problematic children, so to speak. The Act was by and large harsh and paid scant regard to the rights of the children involved. ${ }^{54}$ Furthermore, it overemphasised judicial means of dealing with offending children, thereby ignoring non-judicial means.

As was the case in Malawi before 2010, adoption in Uganda was dealt with separately from the laws that regulated child care. The Adoption $\mathrm{Act}^{55}$ made provision for both in-country adoption and inter-country adoption under strict terms but with minimal regulatory mechanisms. ${ }^{56}$ Ugandan children could be adopted by either British citizens or Ugandan citizens, provided the prospective parent was resident in Uganda or East Africa. Similarly, inter-country adoption was permissible only if it involved British and Ugandan citizens who were resident in East Africa as the adoptive parents. However, these restrictions were routinely circumvented as adoptive parents resorted to guardianship as an alternative and left the country with the children once the orders were granted. ${ }^{57}$

The adoption of the CRC and the African Children's Charter in 1989 and 1990 respectively provided the impetus for the review of all child-related laws in Uganda. Probably the first country to do so, Uganda established the Child Law Review Committee in 1990 to review all child-related laws in order to bring them in line with these treaties. The Committee produced its report in 1992, three years before Uganda adopted a new democratic Constitution in 1995. The Committee's recommendations culminated in the adoption of the Children Act in 1997.

As the Child Law Review Committee had intended, the Children Act is a comprehensive piece of legislation that brings various childrelated laws together under one roof. As far as the question of child care is concerned, the Act sets out from the premise that the child has the right to live with his or her parents and, hence, that the separation of the child from his or her parents can only be justified where it is in

52 Department of Probation and Social Welfare (n 51 above) 29.

53 Department of Probation and Social Welfare 30.

54 Typically, a child older than 10 years could be incarcerated in an approved school for three years or until he or she reached the age of 12 years, whichever was longer. Children younger than 10 could also be committed to approved schools. See sec 9. A child could also be sentenced to between three and five years' imprisonment in a reformatory school. See sec 5 .

55 Ch 216 Laws of Uganda, repealed.

56 See secs 2 and 3.

57 Department of Probation and Social Welfare (n 51 above). 
the child's best interests. ${ }^{58}$ The Act goes further to provide that where such separation is necessary, the best possible substitute care must be provided to the child. ${ }^{59}$ However, the determination of such substitute care is not left entirely to the courts. The Act elaborates a complex but logically-predetermined matrix within which such determination has to be made.

Because of the importance attached to the family, the Act rightly prohibits courts from making care and supervision orders unless they consider these to be 'beneficial to the child'. ${ }^{60}$ Courts may make supervision and care orders only where they are concerned that the child will or is likely to suffer harm. ${ }^{61}$ The scheme established by the Act suggests that courts are obliged to make supervision orders first before a care order may be considered. ${ }^{62}$ In turn, a supervision order cannot be made unless local government councils at the village and sub-country levels have dealt with the issue without success. ${ }^{63}$

In keeping with the recommendation of the Child Law Review Committee that institutionalisation should be used sparingly and for the shortest period of time, ${ }^{64}$ the Children Act regards an approved home as a temporary form of substitute family care for a child until such time as the parents of the child are able to provide adequate care, the child completes his or her three years or attains the age of 18 years, whichever is earlier. ${ }^{65}$ Institutionalisation is also seen a stopgap measure in the search for a family solution, as will be seen below.

The centrality of fosterage to such family solutions is unmistakable. Other care options, such as adoption and inter-country adoption, have to be preceded by fosterage. This explains why the Act dedicates considerable attention to the eligibility requirements of foster parents and the procedures for fosterage. Most notably, non-Ugandan citizens

Sec 4.

As above.

Sec 17.

See sec 21.

See secs 19, 21 and 27 of the Children Act.

63 See sec 22 of the Children Act. It must be noted, however, that a child can be separated from parents in situations of emergency or on an interim basis where the child is likely to suffer harm if such separation is not ordered. See secs 33 and 37 of the Children Act. A supervision order means that the child is left with his or her parents but placed under the supervision of a probation and welfare officer. By contrast, a care order results in the separation of the child from his or her parents and, simultaneously, placement in the care of a warden of an approved home or foster parents. See sec 27 of the Children Act. A care order may be valid for a maximum period of three years or until the child reaches the age of 18 years, whichever is shorter, but the order is reviewable at least once every year. See sec 29 of the Children Act.

64 Department of Probation and Social Welfare (n 51 above) 79-80.

65 See sec 58 of the Children Act. 
are not prohibited from serving as foster parents, but they have to be resident in Uganda. ${ }^{66}$ Furthermore, the foster parents have to be demonstrably capable of raising the child and the wishes of the child have to be considered if these are ascertainable. ${ }^{67}$ Crucially, the Act requires that attempts are made, whenever possible, to place a child with a foster parent who has the same cultural background as the child's parent or comes from the same area of Uganda as the parents of the child. ${ }^{68}$ Similarly, where the child's religion is known, placement must, as far as is possible, be with a foster parent of the same religion, or must involve an undertaking by the foster parent to raise the child in accordance with that child's religion. ${ }^{69}$ All foster care placements are subject to supervision by probation and social welfare officers. ${ }^{70}$ As will be seen below, the requirements related to the child's identity are not specifically prescribed for adoptive parents, understandably so, since fosterage precedes adoption.

In-country adoption and inter-country adoption are the last forms of alternative care recognised by the Children Act, the latter being reserved for 'exceptional circumstances' ${ }^{71}$ The preference for the former to the latter is also indicated by the need to maintain the child's identity as far as is possible built into the foster care scheme discussed above. Whereas foster parents need to be at least 21 years old, prospective adoptive parents have to be at least 25 years old and there has to be an age difference of 21 years between the parent and child, if they apply as single parents, and one of them has to meet these age requirements if they apply jointly as husband and wife. ${ }^{72}$ Single males are precluded from adopting girl children, as are single females from adopting male children, unless there are special circumstances justifying this. 73

Both in-country adoption and inter-country adoption have to be preceded by three years (36 months) of foster care of the specific child to whom the adoption relates. To remove any doubt about the requirement of residence for foster parents and its application to prospective inter-country adoptive parents, section $46(1)(a)$ of the

66 See rule 5(3) of the Foster Care Placement Rules, Second Schedule to the Children Act, made in accordance with sec 43 of the Children Act (Foster Care Placement Rules). Foster parents could be a husband and wife, or a single woman or single man aged above 21. A single man is prohibited from fostering a female child. No similar restriction applies to single women. See rules 5(1)-(2) of the Foster Care Placement Rules. This may be a mere drafting oversight, given that for purposes of adoption, this restriction applies to single females as well. See sec 45(3) of the Children Act.

67 Rule 6 of the Foster Care Placement Rules elaborates a procedure that involves an assessment of the suitability of the prospective adoptive parent, visitation to their home and character vetting.

68 Rule 8 Foster Care Placement Rules.

69 Rule 7 Foster Care Placement Rules.

70 See rule 11 of the Foster Care Placement Rules.

71 Sec 46(1) Children Act.

72 Sec 45(1) Children Act.

73 Sec 45(3) Children Act. 
Children Act expressly requires such parents to prove that they have 'stayed in Uganda for at least three years'. As has been the case in Malawi, the litigation in Uganda on inter-country adoption has focused on this requirement.

Additional requirements include that the prospective parents must not have a criminal record, must be in possession of a recommendation on their suitability to adopt from the country of origin, and must prove that their country of origin will respect and recognise the adoption order. ${ }^{74}$ Mandatory requirements as to consent are stipulated for parents of the child and children aged above 14 years who are the subject of adoption. ${ }^{75}$ As to relatives and other people who may be interested in the child, the court is given a discretion where it appears to it that a person not being a parent of the child has rights or obligations in relation to the child, to require the consent of that person before making the adoption order, ${ }^{76}$ or to ask a probation and welfare officer to prepare a report that may help the court to determine whether there is any other person whose consent to the adoption ought to be obtained. 77

The courts' powers, when presented with an application for an adoption order, are to ensure that the requirements as to consent and the prohibition of financial gain from adoptions and other requirements discussed above have been complied with and, finally, to make the decision whether or not to grant the order based on the welfare of the child. ${ }^{78}$ The adoption recognised under the Children Act is one that terminates the pre-existing parent-child relationship and inaugurates a new one. ${ }^{79}$

The Ugandan scheme for child care described above is systematically and logically set out in a hierarchical structure that begins with the family, assistance to and supervision of the family, the separation of the child and placement with a fit and proper person or foster parent under supervision, placement in an approved home as a stop-gap measure, fosterage as a central pillar of alternative care, incountry adoption and, lastly, inter-country adoption as an exceptional measure.

For the most part, the considerations involved in these steps are in keeping with the human rights standards set out in the African Children's Charter and the CRC. However, for it to work, this scheme assumes that the supply of children in need of care will not surpass the demand from foster parents, and then from adoptive parents, incountry or inter-country. However, this scheme can collapse and has indeed failed to contain the rise of the number of children who need

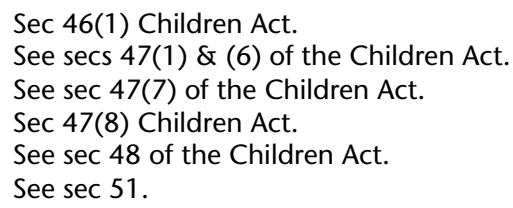


alternative care, resulting in large numbers of institutionalised children and fewer outlets for fosterage and in-country adoption. This is the reason why inter-country adoption has increasingly come into the picture, despite clear attempts to constrain its role.

\section{Judicial responses to restrictions on inter-country adoption}

\subsection{Malawi}

Malawi has seen the emergence of an increasing number of orphanages run by religious organisations or private individuals on a charitable basis. Most of these rely on foreign donor funding. For its part, the state has not built more institutions for the care of children temporarily or permanently deprived of a family environment or in need of state protection. Neither has the state improved or expanded the two schools established by the colonial administration, Mpemba Boys Home and Chilwa Approved School.

It is in this context that adoptions have become an important possibility of alleviating this problem. Before 2006, adoptions were arranged exclusively in favour of Malawian residents. ${ }^{80}$ This changed with the application for the adoption of David Banda by Guy and Madonna Ritchie in 2006. ${ }^{81}$ David was a few months old when the application was made. His mother died when he was just seven days old. Members of his extended family struggled to look after him and subsequently placed him at an orphanage. ${ }^{82}$

After considering the application, its supporting affidavit and the report of the guardian ad litem and satisfying itself that the consent of all persons identified by the Act had been duly obtained, the High Court granted an interim order of adoption for 18 months. By the time the order called for confirmation, the case had attracted considerable local and international attention. The hearing for the final order thus became a matter of huge public interest and prompted the Malawi Human Rights Commission to join the case as amicus curiae.

The main point of controversy in this case was that the Adoption of Children Act did not expressly authorise inter-country adoption. As has been observed earlier, the Act set a residence requirement for all prospective adoptive parents. In this case, the applicants were not Malawian residents, let alone citizens. It was clear that they had come to the country primarily to adopt the child.

80 See Chombo J In re Adoption of CJ (A Female Infant), Adoption Case 1 of 2009 (unreported).

81 See In Re Adoption of David Banda (A Male Infant), Adoption Cause 2 of 2006.

82 As above. 
In his judgment, Nyirenda J (as he then was) took the view that the residence requirement had to be read in light of the Constitution, which recognised a range of children's rights, including their right to development, 83 and the $C R C$, which recognised inter-country adoption as a means of providing alternative care to children who lack parental care or need protection. ${ }^{84}$ According to the judge, the main consideration in adoption cases was the welfare of the child, a term which he used interchangeably with the principle of the best interests of the child commonly used in international law. He thus held that the residence requirement was subservient to and was intended to serve the child's best interests: 85

The scheme that comes out very clearly in that the requirement as to residence was and is intended to protect the child, and to ensure that the adoption is well intended. It is for this reason that ... the requirement as to residence, be it important, is merely a means to an end.

Consequently, while noting that the meaning of residence was not defined in the Act, he held that a literal meaning of residence would defeat the purpose of the Act and not pass constitutional muster. In fact, Nyirenda J eschewed the task of defining 'residence', arguing that the requirement had served its purpose and was no longer necessary. He said: ${ }^{86}$

Thus far it can safely be said that the requirement of residence has served its purpose and that in its absence there are much more weighty considerations in the welfare of our needy children which in themselves would suffice and compel a decision in favour of an adoption by those that are not resident in this country.

Essentially, the judge in this case favoured an approach to the determination of inter-country adoption applications that weighed up all relevant factors in order to reach a decision that was most promotive and protective of the child's welfare. Therefore, although he agreed with the view that inter-country adoption was and should be regarded as a last resort, because of its impact on the pre-existing family and on the child's cultural, linguistic and religious background, he nevertheless held that the following factors weighed in favour of his decision to grant the final adoption order: that the child was in desperate need of parental care; that his relatives had failed to take care of him; that no family in Malawi had offered to adopt the child or to serve as his foster parents; that the applicants were capable of looking after the child; and that the applicants had taken good care of the child during the interim order.

In subordinating the requirement of residence to the welfare principle, the judge in fact raised the significance of section 4 of the

83 Sec 30.

84 This treaty forms part of Malawian law and can be enforced by Malawian courts. See $\mathrm{n} 36$ above.

85 David Banda (n 81 above).

86 As above. 
Adoption of Children Act, which specifies the considerations that the courts must take into account in adjudicating adoption applications ${ }^{87}$ over that of the eligibility requirements for prospective adoptive parents laid down in sections 2 and 3 . In doing so, he interpreted the local statute in a way that was consistent with the spirit of international law.

However, it is unclear what this decision means for the rest of the requirements contained in sections 2 and 3 , such as those pertaining to the age of the applicant, the age difference between the child and the applicant, the gender of the applicant and the child and the requirements as to consent. Can these also be waived depending on what the welfare of the child requires in a particular case?

It is probably this concern that led Chombo J to take a restrictive view of the residence requirement in In re Adoption of C) (A Female Infant). ${ }^{88}$ This case concerned the adoption of a three year-old female child, again by Madonna, this time as a single parent. The mother of the child was 14 years old at the time of birth and died shortly after giving birth. As the whereabouts of the father were unknown, the grandmother of the child looked after her for a short while before she was forced by poverty to leave the child at an orphanage. Curiously, the fact that the High Court had approved the adoption in favour of the same applicant three years earlier did not reduce public interest in this adoption. Having regard to the previous High Court decision on similar facts, all facts on the court's file supported the adoption. The family of the child had given consent to the adoption which it confirmed to the court during the hearing of the application. Furthermore, the report of the guardian ad litem also spoke in favour of the adoption.

Nevertheless, Chombo J refused to grant the adoption order, arguing that the residence requirement had not been met. In making this decision, the judge adopted a literal interpretation of the term 'residence' as 'dwelling permanently or for a considerable time in a particular place'. This view stood in sharp contrast to that espoused earlier by Nyirenda J. ${ }^{89}$ In this case, Chombo J decided to ignore Nyirenda J's decision and instead followed several foreign cases which had interpreted this term in a similarly literal fashion. ${ }^{90}$ Her reasoning

87 The welfare principle is clearly the most important consideration listed under sec 4.

88 n 80 above.

89 Judges of the High Court are not obliged to follow decisions of fellow judges of the same court, although previous decisions made by them and their colleagues are persuasive. Similarly, judges may have regard to comparative foreign case law which is also considered to be of persuasive value.

90 These included Brokelmann v Bar [1971] 3 All ER 29; In Re Adoption Application No 52/1951 [1952] 1 Ch 16; Levene v IRC [1928] AC 217. 
was that the requirement as to residence was important to guard against the possible abuse of the adoption procedure. She said: ${ }^{91}$

The issue of residence, I find, is the key upon which the question of residence rests and it is the very bedrock of protection that our children need: It must therefore not be tampered with.

According to the judge, the welfare principle and the residence requirement were not inconsistent with each other as far as adoption was concerned. The residence requirement served the welfare principle by protecting children from unscrupulous adoptive parents. Since the applicant was not a Malawian resident, her application could not pass muster on this ground.

However, this was not the only reason this adoption application was rejected. Drawing on the provisions of the CRC and the African Children's Charter, Chombo J held that inter-country adoption was to be taken as a measure of last resort having exhausted all in-country care options. According to her, it was not relevant to ask whether the child could be better looked after by a foreign parent, since the quality of life, especially in the West, was generally better than that in Malawi. What was relevant rather was whether there was a real possibility for the care of the child within the country. As the child was being cared for at an orphanage and it had not been proved that such care was inadequate, she found that inter-country adoption could not serve as a substitute for such in-country care. This was one of the most surprising findings of the court, since the adoption was not opposed in court. Since the judge did not give details of the contents of the report of the guardian ad litem, it is not possible to tell whether the report dealt with the conditions of life in the orphanage, the number of other children being looked after there, the sustainability of the orphanage, and other relevant factors. It was crucial for the judge to consider or solicit evidence on this important factor instead of simply shifting the responsibility to the applicant to prove that the orphanage did not provide adequate care. In fact, the Adoption Act does not create any such onus on an applicant for adoption.

All in all, Chombo's decision stunned the world and brought about confusion among Malawians, in particular about the state of the law on inter-country adoption, given that an earlier decision had granted an adoption to the same person and more inter-country adoptions had been granted by the courts in Malawi. ${ }^{92}$ It was widely expected that the case would go to the Malawi Supreme Court of Appeal (MSCA), which it did eventually.

91 Cl (n 80 above).

92 Between 2003 and 2008, 23 inter-country adoptions had been approved in Malawi. In 2009, when this decision was delivered, four inter-country adoptions were authorised. Based on information provided by e-mail by Prof Peter Selman of Newcastle University. 
The MSCA (Munlo CJ writing for the court) was unanimous in overturning the decision of Chombo J. ${ }^{93}$ While noting that the residence requirement was neither unconstitutional nor inconsistent with international law, the Court agreed with Nyirenda J that this term was malleable. Unlike Nyirenda J, who did not venture any specific definition of the term, the MSCA was prepared to offer one. It stated that residence was 'no longer tied to the notion of permanence' and that a person could reside in more than one place, since residence was not constituted by mere physical presence. ${ }^{94}$ The Court went further to state as follows:

Any period of physical presence however short may constitute residence if it is shown that the presence is not transitory; if the period has just began, this will be a question of intention of the party. There is even no need for one to own property in a place in order for him to be capable of residing there.

The MSCA criticised the lower court for ignoring the facts of the case and for preoccupying itself with the protection of 'imaginary children from fraudulent adoptions'. According to the MSCA, the following facts were pertinent: The appellant had come to Malawi to apply for the adoption of a second child; she had shown a willingness to travel frequently to Malawi with both children in order to allow them to relate to their cultural background; and she had proved that she had long-term interests in assisting disadvantaged children in Malawi. All these factors meant, in the words of the Court, that the applicant was not 'a mere sojourner' in Malawi and, hence, that she had met the residence requirement.

As to the second issue, whether inter-country adoption, being a measure of last resort, could not oust available in-country care at an orphanage, the MSCA held that the Adoption of Children Act did not expressly make this a consideration. Nevertheless, the MSCA considered whether allowing the child to continue living in the orphanage was an option in this case that could preclude inter-county adoption and found that it could not. The Court reasoned that the orphanage did not offer the child a family life, and the love and affection that the adoption promised. In the end, since consent to the adoption had been obtained, the adoption was supported by the guardian ad litem and the appellant was found to be a suitable adoptive parent, the MSCA held that there was no reason why the adoption could not be sanctioned.

All in all, although the MSCA appeared to hold that the residence requirement remained relevant, contrary to Nyirenda J's view that it had served its purpose and should now be ignored, the meaning that the MSCA attached to the term is so vacuous that it is not a requirement at all. Any person who comes to Malawi and swears on affidavit that they intend to visit the country regularly with the child 
would meet the Court's definition of residence. On the other hand, some of the comments the MSCA made as proof of intent to reside in Malawi, such as that the applicant had been committed to helping disadvantaged children in Malawi, pointed to an introduction of more onerous obligations than the statute envisaged. Apart from proving capability to look after the child, it should not be expected of the adoptive parent to commit to helping other children in the country.

Overall, the decisions of Nyirenda J and the MSCA were in effect Solomonic and essentially upheld international law to the extent that they vindicated the best interests of the child. However, these decisions were made in a legal context that did not anticipate intercountry adoptions. For example, unlike the adoption ordered by Nyirenda J, which was preceded by an interim order of 18 months, the MSCA's decision was in effect a final order and no reasons were given why an interim order was not deemed appropriate. The fact that the same parent had adopted the first child from the same orphanage might explain this decision, but the fact that the case related to a different child with different needs required a clear justification for the granting of a final order without it being preceded by an interim order. Furthermore, neither adoption order deals with issues related to the logistics for the transfer of the children concerned, the responsibilities of Malawian authorities in ensuring the settlement of the children in the foreign country and to follow up on the children's wellbeing and, more importantly, the responsibilities towards Malawi and the child of the authorities in the receiving country.

Also noteworthy is the fact that the three judgments considered here differ markedly in the ways in which the information about the adoption was managed. ${ }^{95}$ For example, the two High Court judgments provide little relevant information about the family history of the adoptive child, the eligibility of the adoptive parents and the assessment of the social welfare report. Not only are such factually deficient judgments indicative of the inadequacies in the legal requirements for the consideration of inter-country adoptions, but they also make it difficult for the general public to scrutinise the judgments in a better light, and pose a challenge to the adopted children who would want to know and trace their parents when they become adults.

95 In the first case, Nyirenda J seems to have been constrained by what he called the need to respect the privacy of the child. Paradoxically, the name of the child was clearly cited in the heading of the case. The MSCA's decision, on the other hand, contained more details about the child and his family history, although the case heading cited the abbreviated form of the child's name. In either case, the media in Malawi and around the world freely used the names of the children concerned in their coverage of the cases. 


\subsection{Uganda}

Unlike the case in Malawi, the Ugandan Children Act has a well thought-out scheme for dealing with the problem of alternative child care. Inter-country adoption sits at the very bottom of the care options available. Moreover, it is not a stand-alone care option; rather, it is linked to foster care. For a person to be granted an inter-country adoption order, he or she must have fostered a child for at least three years while being resident in Uganda. The requirements for fosterage and those for inter-country adoption form a complete whole in a carefully-constructed hierarchical mosaic of alternative care.

Uganda's system would be consistent with children's rights in general and, more specifically, the best interests of the child if it succeeded in providing appropriate alternative care to all children in need of such care. The evidence suggests that it has not done so and, as a result, many children lack appropriate family care. ${ }^{96}$ It is in this context that legal practitioners have devised a means of circumventing the restrictions on inter-country adoption. The first has been to make applications for guardianship rather than inter-country adoption. The second has been to rely on the express provisions on adoption, but to contend that those requirements are merely directory and not mandatory. Both these options have been endorsed by the courts.

The first strategy was successfully tested in Re Francis Palmer (An Infant) ${ }^{97}$ and In Re Howard Amani Little (An Infant). ${ }^{98}$ This was a consolidated decision in which the three judges delivered contradictory opinions. The lead opinion took the view that the High Court, by virtue of the fact that it has unlimited original jurisdiction, has the power to grant guardianship orders even though neither the Children Act nor any other Act expressly gives it such power. One judge disagreed with this opinion, arguing that such powers were clearly inconsistent with the provisions of the Children Act. Although a third judge expressed disquiet with the suggestion that the clear provisions of the Children Act could be overridden by resorting to guardianship orders, he nevertheless supported the lead opinion on undisclosed grounds.

The initial discomfort with guardianship orders displayed in this case has since been put to rest. In a recent case of Re Deborah Joyce Alitubeera \& Richard Musaba (Infants), ${ }^{99}$ the Court of Appeal had occasion to revisit its earlier ruling. While conceding that the main law dealing with children, the Children Act, did not make specific provision for guardianship, it nonetheless unanimously reaffirmed its earlier decision by appealing to section 139 of the Constitution which

96 See $\mathrm{n} 7$ above and the accompanying notes.

97 Civil Appeal 32 of 2006 (unreported).

98 Civil Appeal 33 of 2006 (unreported).

99 Civil Appeals $70 \& 81$ of 2011 (unreported). 
confers unlimited original jurisdiction on the High Court, ${ }^{100}$ and section 98 of the Civil Procedure Act, ${ }^{101}$ which states that the High Court has inherent jurisdiction to make orders it deems necessary to prevent injustice. The Court also said that the High Court has the power to apply the common law and principles of equity. Read together, the Court of Appeal claimed, these sources of law empowered the High Court to grant guardianship orders.

As an alternative or further basis for this view, the Court relied upon the principle of the child's best interests, which it said was the paramount consideration in all matters concerning the child, and which was codified as a principle of Ugandan law under article 34 of the Constitution, ${ }^{102}$ section 3 of the Children Act, the First Schedule to the Children Act, and the two international treaties, the CRC and the African Children's Charter, both of which the Court said formed part of Ugandan law. This principle, it was held, makes it necessary to grant guardianship orders precisely in situations where inter-country adoption may not be granted due to non-compliance with its requirements, as long as such an order redounds to the child's best interests.

None of the provisions the Court of Appeal relied on expressly gave the Ugandan High Court specific power to make guardianship orders. While it is true that the High Court has inherent powers and unlimited original jurisdiction, the exercise of such powers, surely, is subject to the express provisions of the law. A study of the Children Act also reveals that parliament has withdrawn a significant amount of discretion from the courts to determine the child's best interests by providing a pre-determined framework within which decisions on alternative care have to be made.

The reason why the Court of Appeal felt obliged to authorise the guardianship orders in the cases referred to above has to do with real concerns about the failure of justice that would have ensued had the guardianship orders not been made. The scheme established by the

100 This section provides: '(1) The High Court shall, subject to the provisions of this Constitution, have unlimited original jurisdiction in all matters and such appellate and other jurisdiction as may be conferred on it by this Constitution or other law. (2) Subject to the provisions of this Constitution and any other law, the decisions of any court lower than the High Court shall be appealable to the High Court.'

101 Ch 71 Laws of Uganda. This section provides: 'Nothing in this Act shall be deemed to limit or otherwise affect the inherent power of the court to make such orders as may be necessary for the ends of justice or to prevent abuse of the process of the court.'

102 The closest this section comes to recognising this principle is in subsection (1): 'Subject to laws enacted in their best interests, children shall have the right to know and be cared for by their parents or those entitled by law to bring them up.' Even so, it does not authorise the courts to invoke this principle anyhow, overriding clear laws that give guidance on what the child's best interests are or should be considered. 
legislature, while sound at the general level, was arguably unjust in the specific circumstances of these cases. In Re Deborah Joyce Alitubeera \& Richard Musaba (Infants), ${ }^{103}$ for example, it appears 104 that one of the children was four years old at the time of the application for guardianship. This child was born to a 15 year-old girl who had conceived from a rape incident. She had abandoned the child two days after his birth, leaving him at the verandah of someone's house, who in turn placed the child at an orphanage. The second child was one year old at the time of the High Court ruling. Soon after her birth, the child's parents quarrelled and separated, the mother leaving the child with the father. However, the father could not take care of the child. The High Court described him as a 'worthless drunkard' and an 'exceedingly irresponsible' man who lived in a rudimentary shelter with four other children and who had fathered a total of 17 other children by different women. The child was taken away from him pursuant to a care order which placed the child in the care of an orphanage operated by an NGO. These facts make it compelling for a court to find an immediate solution to the plight of these specific children.

However, since the Court of Appeal invoked provisions that did not expressly give it powers to make guardianship orders, the Court found itself in a legal vacuum as far as the specific considerations governing the granting of guardianship were concerned. ${ }^{105}$ There were no prescribed eligibility requirements for prospective guardians and considerations that the court must bear in mind when making the order. With particular reference to the first consolidated decision of the Court of Appeal referred to earlier, Egonda-Ntende J in Re Adoption of Muwanguzi Perez (An Infant) ${ }^{106}$ lamented as follows:

The Court of Appeal decision, given the conflicting legal positions taken by each judge, provides no authoritative guidance as to how this court should exercise its powers in granting orders of legal guardianship.

103 n 99 above.

104 The facts of the case are muddled and it is thus not easy to tell which set of facts applies to which child.

105 Thus, in Re Deborah Joyce Alitubeera \& Richard Musaba (Infants) (n 99 above), the Court of Appeal had to apply some of the requirements for adoption while considering an application for guardianship. After finding that both children were in need of care, it considered the suitability of the guardians. It found as a fact that the parents had no criminal record, that they were capable of adopting the children in terms of financial capacity and their suitability as parents, and that the children's parents or relatives had given consent to the guardianship. Curiously, the Court was under no misapprehension that the guardianship being sought here was for purposes of inter-country adoption, as the facts clearly stated that the appellants intended to take the children out of Uganda.

106 HCT-00-FD-0170-2008 (unreported). 
The second strategy, which relies on the view that the requirements for inter-country adoption are merely directory, has been given legislative approval in several cases. ${ }^{107}$ These cases were followed in the recent case of Re Adoption of Sharon Asige (An Infant). ${ }^{108}$ This case was not an undisguised application for inter-country adoption. The applicant was a seven year-old orphan who had lost both parents when she was very young. Since the death of her parents, she had lived with her paternal uncle and aunt. The judgment states that the applicants were granted a foster care order, but by the time of the judgment, the three-year period of foster care had not expired. The appellants had also not met the three year residential requirement. ${ }^{109}$ In allowing the adoption in spite of the lack of compliance with residence and foster care requirements, Oguli Oumo J held, in a brief and sparsely-substantiated ruling, that the provisions of section 46 are directory and provide the conditions for which the court may exercise its discretion to grant an adoption order but the guiding principle remains the welfare principle'.110

This ruling does not substantiate its claim that section 46 requirements are merely directory. It is trite that in deciding whether a legal requirement is directory or mandatory, a court has to consider whether the language used is peremptory or not and must extrapolate the mischief that the legislator intended to correct. None of these considerations would support the court's conclusion. The Child Law Review Committee made a clear recommendation that the new child laws should curtail the use of guardianship in order to bypass the requirements for adoption and inter-country adoption. ${ }^{111}$ The Children Act, read as a whole, shows this clear intention. Indeed, by circumventing section 46 requirements, the whole scheme for alternative care established by the Act is rendered nugatory.

\section{Evaluation and conclusion}

Neither Malawi nor Uganda is coping with the rising number of children who lack parental care. Malawi does not have a hierarchised system of alternative care, although the new Child Care, Protection and Justice Act has set the foundation for the development of such a system. This makes it possible in principle to consider all the available alternative care options in a given case, thereby presenting the possibility of choosing a care option that may better serve the interests of the child. The problem is that inter-country adoption is

107 See Re Adoption of Paula Robertson \& Cynthia June Robertson (An Infant), Adoption Cause 31 of 2004 (unreported); Re JN (An Infant), Civil Appeal 22 of 1994 (unreported); Re Michael Benjamin Pietsch, Family Cause 102 of 2008 (unreported). With all due diligence, I did not manage to find these cases.

108 Adoption Cause 144 of 2009 (unreported).

109 The requirements as to age were met.

110 n 108 above.

111 n 51 above. 
not envisioned as an alternative care solution that will be used regularly. Uganda, by contrast, has a more clearly-defined system that considers inter-country adoption as a measure of last resort after incountry options, such as supervision and care orders, foster care and in-country adoption. This system gives preferential treatment to care options which seek to preserve the child's identity and culture, to home-based solutions and to domestic solutions. It may pass muster from a children's rights perspective only if it ensures that all children in need of parental care are catered for, but not when a considerable number of children are left without parental care or in institutional care.

Because of the peripheral role that both countries reserve for intercountry adoption, the legislative arrangements of both countries place onerous restrictions on inter-country adoption. Some of these restrictions are rational and necessary to ensure the protection of the child; others are irrational. Irrational restrictions include the eligibility requirements for adoptive parents that relate to sex or gender and age. In either country, there has to be at least a 21-year age difference between the adoptive child and parent, and a male parent cannot adopt a female child and vice versa. These requirements cannot prevent child abuse, if this is the rationale behind them.

The most problematic restriction, judged from the litigation in both countries, has been that of residence. In Malawi, the relevant law does not define 'residence', while in Uganda, a specific period of three years is stipulated. Furthermore, unlike in Malawi, in Uganda, adoption, whether inter-country or in-country, has to be preceded by foster care.

In both countries, the courts have found it difficult to enforce these restrictions. In Malawi, the courts have either subordinated the residence requirement to the child's best interests or interpreted it in a way that makes it easy for applicants to meet. In Uganda, the courts have either invoked their inherent powers to grant guardianship orders to bypass the restrictions on inter-country adoption, or interpreted residence and fosterage requirements as non-binding.

Curiously, these decisions have been made by the courts in the respective countries with striking similarity and consequences, even though the judges concerned did not have access to the decisions of their counterparts in either country. In both jurisdictions, the courts felt duty-bound to uphold the best interests of the child by rendering clear legal restrictions on inter-country adoption inapplicable. Yet, in doing so, the courts had to engage in significant law making, which has exposed them to the democratic legitimacy attack. The state of the law on inter-country adoption in both countries has also been in a state of confusion caused by some inconsistencies in the decisions made by the courts. A more serious concern relates to the inadequacy of the protective measures that accompany inter-country adoption orders. Since the courts grant these orders in legal environments that do not adequately regulate them, they have found it difficult to 
include measures that would ensure that state authorities in their respective countries and the receiving countries monitor the wellbeing of the adopted children effectively for a reasonable period of time.

These case studies suggest that it is perhaps worthwhile to consider inter-country adoption as a central alternative care option and, hence, to make explicit provision for this. The courts must be allowed to consider all relevant rights of the child in determining whether intercountry adoption, or indeed any other form of alternative care, best serves the interests and rights of the child in a particular case.

Concerns about inter-country adoption can be addressed by legislating protective measures that are rational and relevant. Of particular importance are the substantive and procedural requirements to ensure that the right children are adopted and the right parents are allowed to adopt.

The two legal frameworks discussed in the article spend less time defining who the adoptable child is. Ideally, children who are deprived of family or parental care, either as a result of the death of their parent(s), parental neglect or abandonment, and where no relative is available to take them into care, should be considered adoptable. The eligibility of the adoptive parents is crucial to addressing the much talked-about possibility of inter-country adoption being used as a vehicle for child trafficking. The law could be clearer in prescribing requirements related to criminal records and capacity to look after a child, both materially and psychologically.

Once the substantive question of adoptability and eligibility to adopt has been addressed, more attention has to be given to the procedural protections that would guarantee that the adoption process is fair, workable, efficient and not abused. The article has demonstrated that, while residence may be an important protective measure for children, it has served largely as a barrier to the provision of alternative care to children who need it the most. To the extent that it makes it possible for adoptive parents to establish a prior relationship with a child under the supervision of social workers and relevant authorities, the residence requirement could be relaxed either by reducing the period of residence 12 or allowing for periodic visits to the country by prospective parents. ${ }^{113}$ This may be backed up with a temporary adoption order whereby the adoptive parent is allowed to remove the child from the sending state subject to supervision in the receiving state. A final order could then be made after the consideration of a final report from the authorities in the receiving state attesting to the capability of the adoptive parents to take care of

112 In Uganda, it appears that the residence requirement will be reduced from three years to one year, while the provisions governing the granting of guardianship orders will be amended. Based on an interview with a law reform officer at the Uganda Law Commission, 8 July 2014.

113 Eg, adoptive parents could be allowed to come to the sending state to spend time with the child under supervision for two or more short periods of time, such as a month each, over a year or so. 
the child. These measures cannot be implemented without bilateral agreements between the receiving states and sending states. The measures also cannot be implemented without establishing competent institutions to regulate, facilitate and monitor court orders on inter-country adoption.

The provision of alternative care to children is an obligation that states have to children who lack parental care, and everything should be done to ensure that such children grow up in a family environment where they feel loved and can grow to realise their full potential. 